\title{
Editorial: Structure, Functioning and Conservation of Coastal Vegetated Wetlands
}

\author{
Jonathan Richir ${ }^{1,2 * t}$, Steven Bouillon ${ }^{3 \dagger}$, Sylvie Gobert ${ }^{2,4+}$, Martin W. Skov ${ }^{5 \dagger}$ and \\ Alberto V. Borges ${ }^{1 *+}$ \\ ${ }^{1}$ Chemical Oceanography Unit, FOCUS, University of Liège, Liège, Belgium, ${ }^{2}$ Laboratory of Oceanology, FOCUS, University \\ of Liège, Liège, Belgium, ${ }^{3}$ Department of Earth and Environmental Sciences, KU Leuven, Leuven, Belgium, ${ }^{4}$ Station de \\ Recherches Sous-Marines et Océanographiques (STARESO), Calvi, France, ${ }^{5}$ School of Ocean Sciences, Bangor University, \\ Bangor, United Kingdom
}

Keywords: seagrass, mangrove, saltmarsh, functioning, management, global change, fate of coastal vegetated wetlands

OPEN ACCESS

Edited and reviewed by:

J. Guy Castley,

Griffith University, Australia

${ }^{*}$ Correspondence: Jonathan Richir jonathan.richir@uliege.be Alberto V. Borges alberto.borges@uliege.be

TORCID: Jonathan Richir orcid.org/0000-0001-5890-5724 Steven Bouillon orcid.org/0000-0001-7669-2929 Sylvie Gobert orcid.org/0000-0001-6000-0190 Martin W. Skov orcid.org/0000-0002-7204-3865 Alberto V. Borges orcid.org/0000-0002-5434-2247

Specialty section: This article was submitted to Conservation

a section of the journal Frontiers in Ecology and Evolution

Received: 19 March 2020 Accepted: 22 April 2020 Published: 29 May 2020

Citation:

Richir J, Bouillon S, Gobert S, Skov MW and Borges AV (2020) Editorial: Structure, Functioning and Conservation of Coastal Vegetated Wetlands. Front. Ecol. Evol. 8:134. doi: 10.3389/fevo.2020.00134

\section{Editorial on the Research Topic}

\section{Structure, Functioning and Conservation of Coastal Vegetated Wetlands}

Coastal vegetated wetlands-mangroves, saltmarshes, and seagrass beds, hereafter called coastal wetlands-are marine ecosystems constituted of rooted macrophytes living intertidally or subtidally (Hopkinson et al., 2012, 2019). They occupy a narrow fringe along the shores of all continents except Antarctica (Duarte et al., 2013; Hopkinson et al., 2019). Their global cover is small, yet they are profoundly important to human livelihoods and the regulation of physical, chemical, and biological processes (Borja et al., 2015), and thus for coastal resilience. Mangroves and saltmarshes contribute 2,000-215,000 US\$ ha ${ }^{-1} \mathrm{yr}^{-1}$ to coastal economies through the delivery of numerous ecosystem services (Costanza et al., 2014; Gopal, 2016; Macreadie et al., 2019). The equivalent value for seagrass and algae beds is 29,000 US\$ ha ${ }^{-1} \mathrm{yr}^{-1}$ (Costanza et al., 2014; Dewsbury et al., 2016), while climate regulation alone contributes $1,250 \mathrm{US} \mathrm{ha}^{-1}$ to $>90,000$ US\$ $\mathrm{ha}^{-1}$ (graphical estimates), with variation depending on the valuation approach and type of coastal wetland (Macreadie et al., 2019). Coastal wetlands have a central role in nature-based flood and erosion protection, much to the interest of mitigative coastal zone planning (Bouma et al., 2014). Up to $10 \%$ of all oceanic carbon passes through coastal wetlands (Jennerjahn and Ittekkot, 2002; Dittmar et al., 2006) and their "blue carbon" burial rates, on a per area basis, exceeds that of most terrestrial forests (Howard et al., 2017). Coastal wetlands are important filters of coastal pollutants and pathogens and provide habitat to a wide array of species, including commercially important fisheries stocks and threatened birds and mammals (Borja et al., 2015; Lamb et al., 2017). Unfortunately, land reclamation, deforestation, eutrophication, and other anthropogenic perturbations threaten coastal wetlands. Although area losses are contextually and geographically variable, with some regions showing gain in wetland cover (Ladd et al., 2019), global declines were 25-50\% over the past five decades (Lotze et al., 2006; Duarte et al., 2013; Telesca et al., 2015) and 54-87\% if including the pre-1900s (Davidson, 2014). The array of functional processes-biological, chemical, physical-which in combination give rise to natural benefits, such as coastal protection and carbon storing, are not always well-understood (Macreadie et al., 2019; Rendón et al., 2019). Nevertheless, ongoing declines in the cover of coastal wetlands will undoubtedly diminish the ecosystem services they provide (Waycott et al., 2009) and could initiate a new source of greenhouse gas emissions through remobilization of carbon they store (Belshe et al., 2017). The current concern is that climate change will affect the functioning and future distribution of coastal wetlands (Wernberg et al., 2016), for instance through poleward 
migration (Sorte et al., 2010), rainfall-driven changes to carbon capturing (Sanders et al., 2016) and shifts in the lateral extent of wetlands due to sea level rise (Pergent et al., 2015; Spencer et al., 2016; Schuerch et al., 2018).

While coastal wetlands were understudied in preceding decades (Orth et al., 2006; Duarte et al., 2008) they are now in vogue and are commonly used as model systems to address globally important research frontiers, such as $\mathrm{CO}_{2}$ emissions after disturbance (Lovelock et al., 2017). Numerous methods and metrics have been used to assess their ecological status (Best et al., 2007; Gobert et al., 2009; Marbà et al., 2013; Faridah-Hanum et al., 2019). Yet, the understanding of their functioning and the use of resultant environmental indices is often inconsistent or not practiced, and/or it is reliant on the knowledge of reference conditions and longterm assessment programs, which may or may not exist (Duarte et al., 2017). Conservation and restoration programs carried out worldwide alongside environmental assessments have yielded both encouraging and disappointing impacts on ecosystem functioning and human welfare (Gittman et al., 2019). Restoration successes depend primarily on the habitat type, site selection and the techniques applied (Bayraktarov et al., 2016). It is essential to have a thorough understanding of the causes for variation in the functioning of coastal wetlands to inform the practices that receive considerable global investment for wetland restoration (Simenstad et al., 2006; Bayraktarov et al., 2016). Lack of research knowledge in many areas of coastal wetland functioning hampers decision-making processes concerning their management and the implementation of successful mitigation programs.

We felt the time was ripe for a special issue to bring together recent research into the functioning of coastal wetlands. The present Research Topic placed particular emphasis on the functioning of seagrasses, saltmarsh plants, and mangrove trees as engineering species, and on processes associated with the ecosystem structure that they constitute. Five main research themes were addressed: (i) biogeochemical fluxes and balances of carbon, nutrients, and chemicals, (ii) coastal and seascape ecology, interspecific relationships, and food webs, (iii) patterns and processes of change in cover and distribution of coastal wetlands, (iv) degradation and resilience to environmental and anthropogenic disturbances, including climate change, and (v) the monitoring, management, and restoration of coastal wetlands. These themes are addressed in this Research Topic e-book by 13 contributions from 67 scientists and 11 countries. Most contributions were made by researchers from the United Kingdom (32), the USA (9), Belgium (8), Spain (5), and France (5), with only two from Africa (Kenya) and Middle East (Israel). All but two of the articles concern seagrass beds and saltmarshes, given the geographic origin of the scientists and research institutes involved. These geographical and system associated biases were unintended and purely a reflection of the manuscript submissions received by the editorial team. The patterns and responses presented in the 13 papers of the Research Topic ebook still provide useful insights for other regions, as well as for other wetland systems.
The Research Topic e-book starts with a review that demonstrates how crucial positive species interactions of mutualism, commensalism, and facilitation are to the restoration and disturbance-recovery of mangroves and saltmarshes (Renzi et al.). Following that is an experimental study on mangrove tree seedling development, which outlines how mangroves could mitigate climate change in the context of rising atmospheric $\mathrm{CO}_{2}$ and increasing tidal flood duration (Jacotot et al.). These first two studies illustrate that successful protection and restoration of coastal wetlands require in-depth knowledge of the biology and dynamics of the species that underpin ecosystem functioning. Sediment dynamics, in particular accretion and erosion, are abiotic processes that greatly influence the distribution and resilience of coastal wetlands, and thus the success of restoration and environmental compensation measures-a point that is exemplified in three saltmarsh papers (De Battisti et al.; McCloskey et al.; Taylor et al.). The spatial complexity of saltmarshes, as an integrated system of vegetated platforms, tidal channels and ponds, gives rise to contextually variable biogeochemistry and resilience to disturbance, as illustrated by two studies (Huertas et al.; Hutchings et al.). Intuitively, one would expect livestock grazing of saltmarshes to have a negative impact on carbon stock; yet a broad-scale study in the UK shows carbon stores were un-affected by variation in the intensity of sheep grazing, probably because grazing has minimal impact on carbon stores relative to the influence of environmental context (Harvey et al.). The Research Topic ebook includes five studies on seagrass beds. These explore an array of topics, from degradation to restoration, at the scale of individual species to whole ecosystems. An experimental, in situ test validates a simple and cost effective method for restoring Zostera marina beds, using seeds packed in hessian bags (Unsworth et al.). In response to water quality degradation, seagrasses exhibit various changes in morphology and physiology. The response of $Z$. marina is tested in controlled laboratory conditions to provide a consistent set of biological response variables to light deprivation and to assign minimum light thresholds for that species (Bertelli and Unsworth). A study shows Posidonia oceanica is the highest marine producer of two organosulfur compounds, dimethylsulfoniopropionate and dimethylsulfoxide, that are central to the marine sulfur cycle and which have mitigating influence on the greenhouse gas effect (Richir et al.). Another study highlights the dichotomous dynamics of seagrass seascapes, as influenced by natural and anthropogenic (anchoring) factors (Abadie et al.). The final paper of the e-book is an 18-month experimental study that demonstrates that seagrass removal in a multi-species tropical meadow causes surface erosion, the diminishing of carbon stock, as well as changes in the local composition of faunal communities (Githaiga et al.).

The novel research findings on the functioning of coastal wetlands published in these 13 studies bring new insights into several research gaps highlighted in this editorial. Although a wide variety of topics have been covered, a common message arises here, which is that we have many shortcomings in our understanding of fundamental ecosystem processes, in particular those associated with ecosystem service delivery. 
This common message is generalisable to all marine and tidal wetlands worldwide. Thus, the e-book underscores the need for continued effort to provide a solid knowledgebase on coastal wetlands, in support of effective management practice, conservation and restoration, and for the benefit of future generations.

\section{REFERENCES}

Bayraktarov, E., Saunders, M. I., Abdullah, S., Mills, M., Beher, J., Possingham, H. P., et al. (2016). The cost and feasibility of marine coastal restoration. Ecol. Appl. 26, 1055-1074. doi: 10.1890/15-1077

Belshe, E. F., Mateo, M. A., Gillis, L., Zimmer, M., and Teichberg, M. (2017). Muddy waters: unintentional consequences of blue carbon research obscure our understanding of organic carbon dynamics in seagrass ecosystems. Front. Mar. Sci. 4:125. doi: 10.3389/fmars.2017.00125

Best, M., Massey, A., and Prior, A. (2007). Developing a saltmarsh classification tool for the European water framework directive. Mar. Pollut. Bull. 55, 205-214. doi: 10.1016/j.marpolbul.2006.08.036

Borja, A., Murillas-Maza, A., Pascual, M., and Uyarra, M. C. (2015). "Marine and coastal ecosystems: delivery of goods and services, through sustainable use and conservation," in Ecosystem Services and River Basin Ecohydrology, eds L. Chicharo, F. Müller, and N. Fohrer (Dordrecht: Springer), 83-105.

Bouma, T. J., Belzen, J., van, Balke, T., Zhu, Z., Airoldi, L., Blight, A. J., et al. (2014). Identifying knowledge gaps hampering application of intertidal habitats in coastal protection: opportunities \& steps to take. Coast. Eng. 87, 147-157. doi: 10.1016/j.coastaleng.2013.11.014

Costanza, R., Groot, R., Sutton, P., van der Ploeg, S., Anderson, S. J., Kubiszewski, I., et al. (2014). Changes in the global value of ecosystem services. Glob. Environ. Change 26, 152-158. doi: 10.1016/j.gloenvcha.2014.04.002

Davidson, N. C. (2014). How much wetland has the world lost? Long-term and recent trends in global wetland area. Mar. Freshw. Res. 65, 934-941. doi: 10.1071/MF14173

Dewsbury, B. M., Bhat, M., and Fourqurean, J. W. (2016). A review of seagrass economic valuations: gaps and progress in valuation approaches. Ecosyst. Serv. 18, 68-77. doi: 10.1016/j.ecoser.2016.02.010

Dittmar, T., Hertkorn, N., Kattner, G., and Lara, R. J. (2006). Mangroves, a major source of dissolved organic carbon to the oceans. Glob. Biogeochem. Cycles 20:GB1012. doi: 10.1029/2005GB002570

Duarte, B., Neto, J. M., Marques, J. C., Adams, J. B., and Caçador, I. (2017). Marine angiosperm indices used to assess ecological status within the Water Framework Directive and South African National Water Act : learning from di ff erences and common issues. Ecol. Indic. 83, 192-200. doi: 10.1016/j.ecolind.2017.07.032

Duarte, C. M., Dennison, W. C., Orth, R. J. W., and Carruthers, T. J. B. (2008). The charisma of coastal ecosystems: addressing the imbalance. Estuar. Coasts 31, 233-238. doi: 10.1007/s12237-008-9038-7

Duarte, C. M., Losada, I. J., Hendriks, I. E., Mazarrasa, I., and Marbà, N. (2013). The role of coastal plant communities for climate change mitigation and adaptation. Nat. Clim. Change 3, 961-968. doi: 10.1038/nclimate1970

Faridah-Hanum, I., Yusoff, F. M., Fitrianto, A., Ainuddin, N. A., Gandaseca, S., Zaiton, S., et al. (2019). Development of a comprehensive mangrove quality index (MQI) in Matang Mangrove: assessing mangrove ecosystem health. Ecol. Indic. 102, 103-117. doi: 10.1016/j.ecolind.2019. 02.030

Gittman, R. K., Baillie, C. J., Arkema, K. K., Bennett, R. O., Benoit, J., Blitch, S., et al. (2019). Voluntary restoration: mitigation's silent partner in the quest to reverse coastal wetland loss in the USA. Front. Mar. Sci. 6:511. doi: 10.3389/fmars.2019.00511

Gobert, S., Sartoretto, S., Rico-Raimondino, V., Andral, B., Chery, A., Lejeune, P., et al. (2009). Assessment of the ecological status of Mediterranean French coastal waters as required by the Water Framework Directive using the Posidonia oceanica Rapid Easy Index: PREI. Mar. Pollut. Bull. 58, 1727-1733. doi: 10.1016/j.marpolbul.2009.06.012

\section{AUTHOR CONTRIBUTIONS}

All authors listed have made a substantial, direct and intellectual contribution to the work, and approved it for publication. JR is a postdoctoral researcher at the Fonds National de la Recherche Scientifique (FNRS) and AVB is a research director at the FNRS.

Gopal, B. (2016). Should 'wetlands' cover all aquatic ecosystems and do macrophytes make a difference to their ecosystem services? Folia Geobot. 51, 209-226. doi: 10.1007/s12224-016-9248-x

Hopkinson, C. S., Cai, W. J., and Hu, X. (2012). Carbon sequestration in wetland dominated coastal systems-a global sink of rapidly diminishing magnitude. Curr. Opin. Environ. Sustain. 4, 186-194. doi: 10.1016/j.cosust.2012.03.005

Hopkinson, C. S., Wolanski, E., Brinson, M. M., Cahoon, D. R., and Perillo, G. M. E. (2019). "Coastal Wetlands: A Synthesis," in Coastal Wetlands, Second Edition: An Integrated and Ecosystem Approach, eds G. M. E. Perillo, E. Wolanski, D. R. Cahoon, and C. S. Hopkinson (Elsevier), 1-75.

Howard, J., Sutton-Grier, A., Herr, D., Kleypas, J., Landis, E., Mcleod, E., et al. (2017). Clarifying the role of coastal and marine systems in climate mitigation. Front. Ecol. Environ. 15, 42-50. doi: 10.1002/fee.1451

Jennerjahn, T. C., and Ittekkot, V. (2002). Relevance of mangroves for the production and deposition of organic matter along tropical continental margins. Naturwissenschaften 89, 23-30. doi: 10.1007/s00114-001-0283-x

Ladd, C. J. T., Duggan-Edwards, M. F., Bouma, T. J., Pagès, J. F., and Skov, M. W. (2019). Sediment supply explains long-term and large-scale patterns in salt marsh lateral expansion and erosion. Geophys. Res. Lett. 46, 11178-11187. doi: 10.1029/2019GL083315

Lamb, J. B., van de Water, J. A., Bourne, D. G., Altier, C., Hein, M. Y., Fiorenza, E. A., et al. (2017). Seagrass ecosystems reduce exposure to bacterial pathogens of humans, fishes, and invertebrates. Science 355, 731-733. doi: $10.1126 /$ science.aal1956

Lotze, H. K., Lenihan, H. S., Bourque, B. J., Bradbury, R. H., Cooke, R. G., Kay, M. C., et al. (2006). Depletion, degradation, and recovery potential of estuaries and coastal seas. Science 312, 1806-1809. doi: 10.1126/science.1128035

Lovelock, C. E., Fourqurean, J. W., and Morris, J. T. (2017). Modeled $\mathrm{CO}_{2}$ emissions from coastal wetland transitions to other land uses: tidal marshes, mangrove forests, and seagrass beds. Front. Mar. Sci. 4:143. doi: 10.3389/fmars.2017.00143

Macreadie, P. I., Anton, A., Raven, J. A., Beaumont, N., Connolly, R. M., Friess, D. A., et al. (2019). The future of Blue Carbon science. Nat. Commun. 10: 3998. doi: 10.1038/s41467-019-11693-w

Marbà N., Krause-Jensen, D., Alcoverro, T., Birk, S., Pedersen, A., Neto, J. M., et al. (2013). Diversity of European seagrass indicators: patterns within and across regions. Hydrobiologia 704, 265-278. doi: 10.1007/s10750-012-1403-7

Orth, R. J., Carruthers, T. J. B., Dennison, W. C., Duarte, C. M., Fourqurean, J. W., Heck, K. L., et al. (2006). A global crisis for seagrass ecosystems. Bioscience 56, 987-996. doi: 10.1641/0006-3568200656987:AGCFSE2.0.CO;2

Pergent, G., Pergent-Martini, C., Bein, A., Dedeken, M., Oberti, P., Orsini, A., et al. (2015). Dynamic of Posidonia oceanica seagrass meadows in the northwestern Mediterranean: could climate change be to blame? C. R. Biol. 338, 484-493. doi: 10.1016/j.crvi.2015.04.011

Rendón, O. R., Garbutt, A., Skov, M., Möller, I., Alexander, M., Ballinger, R et al. (2019). A framework linking ecosystem services and human well-being: saltmarsh as a case study. People Nat. 1, 486-496. doi: 10.1002/pan3.10050

Sanders, C. J., Maher, D. T., Tait, D. R., Williams, D., Holloway, C., Sippo, J. Z., et al. (2016). Are global mangrove carbon stocks driven by rainfall? J. Geophys. Res. Biogeosci. 121, 2600-2609. doi: 10.1002/2016JG003510

Schuerch, M., Spencer, T., Temmerman, S., Kirwan, M. L., Wolff, C., Lincke, D., et al. (2018). Future response of global coastal wetlands to sea-level rise. Nature 561, 231-234. doi: 10.1038/s41586-018-0476-5

Simenstad, C., Reed, D., and Ford, M. (2006). When is restoration not? Incorporating landscape-scale processes to restore self-sustaining ecosystems in coastal wetland restoration. Ecol. Eng. 26, 27-39. doi: 10.1016/j.ecoleng.2005.09.007 
Sorte, C. J. B., Williams, S. L., and Carlton, J. T. (2010). Marine range shifts and species introductions: comparative spread rates and community impacts. Glob. Ecol. Biogeogr. 19, 303-316. doi: 10.1111/j.1466-8238.2009. 00519.x

Spencer, T., Schuerch, M., Nicholls, R. J., Hinkel, J., Lincke, D., Vafeidis, A. T., et al. (2016). Global coastal wetland change under sea-level rise and related stresses: the DIVA Wetland Change Model. Glob. Planet. Change 139, 15-30. doi: 10.1016/j.gloplacha.2015.12.018

Telesca, L., Belluscio, A., Criscoli, A., Ardizzone, G., Apostolaki, E. T., Fraschetti, S., et al. (2015). Seagrass meadows (Posidonia oceanica) distribution and trajectories of change. Sci. Rep. 5:12505. doi: 10.1038/srep 12505

Waycott, M., Duarte, C. M., Carruthers, T. J., Orth, R. J., Dennison, W. C., Olyarnik, S., et al. (2009). Accelerating loss of seagrasses across the globe threatens coastal ecosystems. Proc. Natl. Acad. Sci. U.S.A. 106, 12377-12381. doi: 10.1073/pnas.0905620106
Wernberg, T., Arenas, F., Olabarria, C., Thomsen M. S., and Mohring, M. B. (2016). "Threats to ecosystem engineering macrophytes: climate change," in Marine Macrophytes as Foundation Species, ed E. Ólafsson (Science Boca Raton, FL: Publisher/CRC Press), 201-225.

Conflict of Interest: The authors declare that the research was conducted in the absence of any commercial or financial relationships that could be construed as a potential conflict of interest.

Copyright $\odot 2020$ Richir, Bouillon, Gobert, Skov and Borges. This is an open-access article distributed under the terms of the Creative Commons Attribution License (CC BY). The use, distribution or reproduction in other forums is permitted, provided the original author(s) and the copyright owner(s) are credited and that the original publication in this journal is cited, in accordance with accepted academic practice. No use, distribution or reproduction is permitted which does not comply with these terms. 